ISSN 1991-8631

Original Paper

http://indexmedicus.afro.who.int

\title{
Preliminary assessment of the influence of environment on growth parameters and yield in some genotypes of Hibiscus sabdariffa $\mathbf{L}$. from Niger
}

\author{
Yacoubou BAKASSO ${ }^{1 *}$, Mahamane SAADOU ${ }^{1}$, Jean-Didier ZONGO ${ }^{2}$, \\ Jojo BAIDOU FORSON ${ }^{3}$ and Abass TOUJANI ${ }^{4}$ \\ ${ }^{1}$ University A. M. of Niamey, Sciences Faculty, Biology Department, BP 10662 Niamey, Niger. \\ ${ }^{2}$ University of Ouagadougou, UFR SVE, BP 7021 Ouagadougou 03, Burkina Faso. \\ ${ }^{3}$ United Nation University Institute for Natural Resources in Africa, PMB, KIA, Accra, Ghana. \\ ${ }^{4}$ INRAN Maradi, Niger. \\ * Corresponding author, E-mail: bakasso@yahoo.com
}

\begin{abstract}
The development of cultivars with a high level of performance over a wide range of environmental conditions is the goal of most crop breeding programmes. Preliminary study on the performance of 36 genotypes of Hibiscus sabdariffa L. was conducted during the 2002 rainy season at two locations representing two different agro-ecological zones of Niger. Number of days to flowering and days to $50 \%$ maturity were recorded. At maturity, plant height, basal diameter of the principal stem, number of branches per plant, total seed weight per plant and 100-seeds weight were measured. The ANOVA showed high significance of genotype and location for all traits. The variability was mainly attributed to differences in soil type and climatic conditions during the growing season, since ecotypes were fixed. The results suggest a genotype $\mathrm{x}$ environment interaction. It is, therefore, important to consider the environmental factor in $H$. sabdariffa breeding programs. (C) 2009 International Formulae Group. All rights reserved.
\end{abstract}

Keywords: Hibiscus sabdariffa L., interaction, ecotype x environment, Niger.

\section{INTRODUCTION}

Hibiscus sabdariffa L., also known as Roselle, is an annual plant belonging to the Malvaceae family. It is cultivated in tropical and subtropical regions of the world for its calyxes, leaves, fibres and seeds, in nutritional, medicinal and industrial uses (Morton, 1987; Bérhaut, 1979; Rhodin and Panchoo, 1990; Mansour, 1975; Southern University Research and Extension Center, 2006). In Africa, roselle is commonly cultivated in the savanna and semi-arid areas (Schippers, 2000).

H. sabdariffa $\mathrm{L}$. is well adapted to the Sahelian and northern Sudanian climatic conditions that prevail in the southern part of the Republic of Niger. Roselle plays an important role in household food economy, although it is cultivated on smaller land area compared to the staple millet crop. Roselle is usually planted on small plots or as field borders of rainfed cereal crops, to cater for subsistence needs of farmer households.

Earlier research that focused on environmental influence on $H$. sabdariffa (Mansou, 1975) showed significant effects of temperature and light. It was reported that the highest percentage of germination and the most rapid emergence occurred at $25{ }^{\circ} \mathrm{C}$. In addition, growth of $H$. sabdariffa was proportional to temperature, day length, and flowering, the plants showing an ambiphotoperiodic reaction. The crop will grow well on fertile soils, but can also tolerate moderately fertile sandy and loamy soils. Roselle developmental cycle requires 4 to 8 months with a nighttime temperature higher than $21{ }^{\circ} \mathrm{C}$. In addition, Hibiscus sabdariffa required a monthly rainfall ranging from 130 
to $260 \mathrm{~mm}$ in the first 3 to 4 months of growth.

High productive potentials have been reported for Roselle grown under rainfed, through various agronomic practices such as weeding and spacing (Babatunde and Zechariah, 2001); nitrogenous fertilizer (Babatunde et al., 2002); intercropping, sowing dates, intra-row spacing and nitrogen fertilizer (Babatunde, 2003). Abou-El-Seoud et al. (1997) reported that K-fertilization stimulates carbohydrate synthesis in Roselle plant leaves. Nabila and Ali (2002) found that animal manure as well as foliar application of micronutrients at flower initiation and fruit setting enhanced plant height, number of branches, fruits and mass production as well as fresh and dry weights of sepals per plant or per feddan.

In Niger 4 agroclimatic zones were determined for the rainfed agriculture corresponding to: - (1) precipitation between $200 \mathrm{~mm}$ to $400 \mathrm{~mm}$, - (2) precipitation between 400 to $600 \mathrm{~mm}$, - (3) precipitation between 600 to $800 \mathrm{~mm}$, - (4) precipitation > $800 \mathrm{~mm}$ (Figure 1). To better understand the implications of environmental factors on $H$. sabdariffa growth and yield potential under local agroclimatic conditions, we conducted environmental studies at two experimental stations to ascertain the effects of climatic (rain) and soil factors on growth parameters and yield in 36 genotypes of Hibiscus sabdariffa $\mathrm{L}$.

\section{MATERIALS AND METHODS}

Thirty-six genotypes of Hibiscus sabdariffa L. were collected from the agriculturally-active southern band of Niger (Figure 1). The genotypes were evaluated during the 2002 cropping season at the national agricultural research stations located at Gaya (310 km East from Niamey, 11 ${ }^{\circ} 53$ 'N and $3^{\circ} 19^{\prime}$ E) in the northern Sudanian agroclimatic zone and Maradi $(657 \mathrm{~km}$ East of Niamey, $13^{\circ} 28^{\prime} \mathrm{N}$ and $7^{\circ} 05^{\prime} \mathrm{E}$, and at $368 \mathrm{~m}$ of altitude) which is located in a Sahelian agroclimatic zone. The soil and climate characteristics are presented in table 1 .

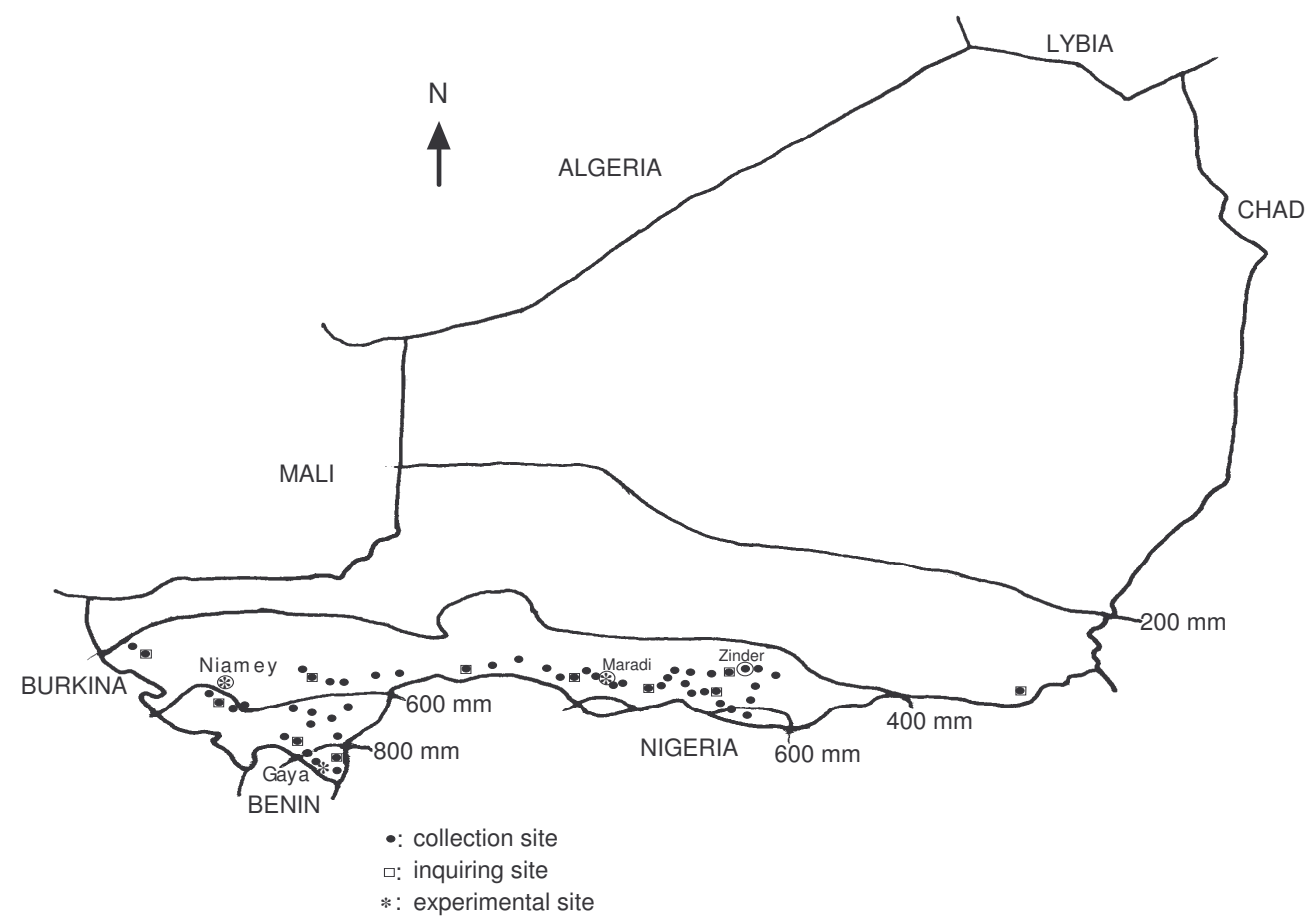

Figure 1: Ecotypes origin and experimental sites. 
Table 1: Characteristics of climate and soil for the two different localities used as experimental stations.

\begin{tabular}{lll}
\hline Characteristics & Gaya & Maradi \\
\hline Soil: & & \\
soil type & tropical ferruginous & tropical ferruginous deep \\
acid & $\mathrm{p}^{\mathrm{H}=5.1}$ & $\mathrm{p}^{\mathrm{H}}=6.0$ \\
sand & $86 \%$ & $96.7 \%$ \\
mud & $5.8 \%$ & $2.8 \%$ \\
clay & $8.17 \%$ & $3 \%$ \\
total nitrogen & $0.02 \%$ & $0.005 \%$ \\
organic carbon & $0.3 \%$ & $0.22 \%$ \\
phosphorus & $101 \mathrm{ppm}$ & $1.6 \mathrm{ppm}$ \\
capacity of cationic interchange & $1.04 \mathrm{meq} / 100 \mathrm{~g}$ & $1.0 \mathrm{meq} / 100 \mathrm{~g}$ \\
Climate: & & \\
Pluviometric index (PI) & $\mathrm{PI}>600 \mathrm{~mm}$ & $400 \mathrm{~mm}<\mathrm{PI}<600 \mathrm{~mm}$ \\
Relative humidity (RH) & $23 \%<\mathrm{RH}<80.5 \%$ & $18 \%<\mathrm{RH}<70.5 \%$ \\
Temperature (T) & $25^{\circ} 84<\mathrm{T}<33^{\circ} 57$ & $19^{\circ}<\mathrm{T}<32^{\circ} 8$ \\
Thermic amplitude & $7^{\circ} 73$ & $13^{\circ} 8$ \\
Daylight & 6.8 to 8.7 hours & 6.9 to $9.3 \mathrm{hours}$ \\
Rainfall average (1992-2001) & $856.9 \mathrm{~mm}$ & $475.7 \mathrm{~mm}$ \\
\hline
\end{tabular}

(Source: sites data; Saadou, 1990)

In the Gaya area, the duration of the rainy season is between 120 and 146 days while in the Maradi area it is between 80 and 100 days (Sivakumar et al., 1993). Over the last 10 years (1992 to 2001), the average rainfall recorded was $805.59 \mathrm{~mm}$ over 57 days and during the 2002 rainy season; $856.9 \mathrm{~mm}$ were recorded during 58 days at Gaya station. For the same period, the Maradi station recorded $475.7 \mathrm{~mm}$ over 37 days and during 2002 rainy season $510.7 \mathrm{~mm}$ of rain were collected over 40 days.

A randomized complete block design with three replications was used to test the influence of environmental factors on $H$. sabdariffa ecotypes. In each block, each genotype was represented by a $6 \mathrm{~m}$ long row, in which 5 mounds were positioned every 1.5 $\mathrm{m}$. Successive rows were $1.5 \mathrm{~m}$ apart and the blocks were $3 \mathrm{~m}$ apart. At least 5 seeds were sown on each mound. One week after germination, the plants were thinned to 2 plants per mound and to 1 plant per mound at the first weeding.

At each of the two locations, the following data were recorded: number of days to flowering (DFl); number of days to $50 \%$ maturity (Dmat), maturity was determined when the capsules were reddish-brown and the seeds were blackish; plant height at maturity (PHM); the basal diameter of the principal stem at maturity (Dia); number of branches per plant at maturity $(\mathrm{NbB})$; total seeds weight per plant (SW); and 100-seeds weight (HSW).

The data were analyzed, using SAS (1987) software, as a mixed model with fixed treatments and random locations following McIntoch (1983), as shown in table 2.

The following formula was used to determine mean squares.

$$
\mathrm{M}=\frac{\sum(\mathrm{X}-\overline{\mathrm{X}})^{2}}{\mathrm{n}-1}
$$

If the $\mathrm{F}$ determined with residual error was significant, another $\mathrm{F}$ was estimated with the mean square of interaction for the better interpretation.

$$
\mathrm{F}_{\mathrm{e}}=\frac{\mathrm{M}_{\text {ecotype }}}{\mathrm{M}_{\text {localition } * \text { ecotype }}}
$$


and

$$
F_{b}=\frac{M_{\text {block }}}{M_{\text {localition * block }}}
$$

The F expressions were:

$$
\mathrm{F}_{\mathrm{e}}=\frac{\mathrm{M}_{3}}{\mathrm{M}_{4}}
$$

and

$$
F_{b}=\frac{M_{1}}{M_{2}}
$$

\section{RESULTS}

The results presented in table 3 and table 4 show that all the genotypes differ significantly for most of the studied traits $(\mathrm{p}<$ 0.01). Also, all traits were largely variable among and within the experimental sites. Indeed, regarding the flowering, at Gaya, the first genotype flowered 74 days after sowing whereas the last one flowered at 111 days after sowing. Similarly at Maradi, a gap of 33 days was observed between the first plant to flower and the last one. The variation in plant height was about $78 \mathrm{~cm}$ at Gaya and $103 \mathrm{~cm}$ at Maradi. The observed range of variations in number of branches was respectively 15 at Gaya and 20 at Maradi. Similarly, mean differences in ecotype diameter at plant base were $1.33 \mathrm{~cm}$ at Gaya and $2 \mathrm{~cm}$ at Maradi, respectively. The recorded performance for all the traits pointed out the existence of significant variations within and among the studied ecotypes.

The ANOVA mixed model, with pooled error as source of error, showed that differences among genotypes, for all the traits studied, were significant. Location, and location x genotype, as sources of variation, were also significant for all variables (Table 5). Block $x$ location as sources of variation were significant for Dmat, PHM, Dia, NbR but not for the remaining traits. When ANOVA mixed models for which interaction was the source of error was performed (McIntosh 1983) there were significant location variations for all variables. For genotypes, variations were significant for all variables except the total seed weight per plant (Table 6). The LSD test confirmed the difference between the two locations for all the studied variables (Table 7).

\section{DISCUSSION}

The analysis of variance showed highly significant variation among genotypes, for almost all the traits studied. Since variability among genotypes is the basis of genetic improvement for any species, the findings pointed out the feasibility of genetic improvement of $H$. sabdariffa in Niger for the several uses by small farmers to increase its marketability and profitability.

The ANOVA mixed model (location as random factor and variety as fixed factor) showed that, for all traits, location effect and location $\mathrm{x}$ genotype interaction are highly significant. The results illustrate that the greater part of the environment effect on Hibiscus sabdariffa L. occurs during the growth stage. Since the genotypes were fixed and locations were random, the observed variability was mainly the result of differences in soil type and climatic conditions during the growing season. The significant location $\mathrm{x}$ genotype interactions indicates that all genotypes do not respond the same way across environments, except the total seeds weight per plant. According to Mansour (1975), $H$. sabdariffa is a heat-loving plant. Its growth and development are dependent on the prevailing day length. The dry weights of herb, calyxes and total plant were significantly increased by all fertilization treatments (Ibrahim et al., 1984). Roselle responds to nitrogen early in its development (Rhoden et al., 1993). Similar results were obtained by Salah (1977) for Roselle response to nitrogen, potassium, calcium, etc. However, within each location the soil characteristics do not vary significantly from the representative values already described under the materials and methods section. But the representative soil conditions differ across the two locations particularly for phosphorus. In addition, across the two locations, rainfall is a very important distinguishing variable factor. 
Table 2: F-ratios used to test effects for randomised complete block experiments combined over locations.

\begin{tabular}{lllc}
\hline $\begin{array}{l}\text { Sources of } \\
\text { variation }\end{array}$ & Ddl & Mean squares & F-tests \\
\hline Locations & $1-1$ & $\mathrm{M}_{1}$ & $\mathrm{M}_{1} / \mathrm{M}_{\mathrm{e}}$ \\
Blocks/Locations & $1(\mathrm{r}-1)$ & $\mathrm{M}_{2}$ & $\mathrm{M}_{2} / \mathrm{M}_{\mathrm{e}}$ \\
Genotype & $\mathrm{t}-1$ & $\mathrm{M}_{3}$ & $\mathrm{M}_{3} / \mathrm{M}_{\mathrm{e}}$ \\
Location*Genotype & $(1-1)(\mathrm{t}-1)$ & $\mathrm{M}_{4}$ & $\mathrm{M}_{4} / \mathrm{M}_{\mathrm{e}}$ \\
Pooled Error & $1(\mathrm{r}-1)(\mathrm{t}-1)$ & $\mathrm{M}_{\mathrm{e}}$ & \\
\hline
\end{tabular}

Table 3: Mean performance of genotypes at Gaya (northern Sudanian agroclimatic site).

\begin{tabular}{lccccl}
\hline Parameter & Mean & Minimum & Maximum & CV & F \\
\hline DFl & 86.6 & 74.3 & 111.3 & 2.93 & $31.52^{* *}$ \\
DMat & 119.0 & 105.0 & 140.7 & 1.47 & $117.18^{* *}$ \\
PHM $(\mathrm{cm})$ & 150.6 & 111.3 & 189.3 & 5.76 & $18.48^{* *}$ \\
Dia $(\mathrm{cm})$ & 3.8 & 3.0 & 4.3 & 8.33 & $4.95^{* *}$ \\
NbR & 22.4 & 14.7 & 31.3 & 13.63 & $5.49^{* *}$ \\
SW $(\mathrm{g})$ & 443.2 & 140.0 & 1046.7 & 45.75 & $2.64 * *$ \\
HSW $(\mathrm{g})$ & 3.32 & 2.3 & 4.0 & 8.71 & $7.38^{* *}$ \\
\hline
\end{tabular}

** : significant at $1 \%$ level; CV : Coefficient of variation ; F : F-test (Fisher)

$\mathrm{DFl}$ : number of days to flowering Dmat : number of days to $50 \%$ maturity, PHM : plant height at maturity, Dia : the basal diameter of the principal stem at maturity, $\mathrm{NbB}:$ number of branches per plant at maturity, $\mathrm{SW}:$ total seed weight per plant, HSW : 100-seed weight.

Table 4: Mean performance of genotypes at Maradi (Sahelian agroclimatic site).

\begin{tabular}{lccccc}
\hline arameter & Mean & Minimum & Maximum & CV & F \\
\hline DFl & 78.3 & 61.7 & 93.3 & 2.52 & $48.38^{* *}$ \\
DMat & 116.2 & 101.7 & 134.3 & 1.44 & $65.99 * *$ \\
PHM $(\mathrm{cm})$ & 164.7 & 106.7 & 213.3 & 4.71 & $33.75^{* *}$ \\
Dia $(\mathrm{cm})$ & 2.9 & 2.0 & 4.0 & 12.51 & $2.74^{* *}$ \\
NbR & 37.7 & 25.3 & 45.0 & 10.90 & $2.74 * *$ \\
SW $(\mathrm{g})$ & 130.0 & 61.0 & 186.7 & 22.55 & $3.03^{* *}$ \\
HSW $(\mathrm{g})$ & 3.9 & 3.0 & 5.0 & 4.37 & $19.81^{* *}$ \\
\hline
\end{tabular}

** : Significant at $1 \%$ level; CV: Coefficient of variation; F: F-test (Fisher);

$\mathrm{DFl}$ : number of days to flowering Dmat : number of days to $50 \%$ maturity, PHM : plant height at maturity, Dia : the basal diameter of the principal stem at maturity, $\mathrm{NbB}:$ number of branches per plant at maturity, SW : total seed weight per plant, HSW : 100-seed weight.

Table 5: Analysis of variance, with pooled error as error sources (mixed models).

\begin{tabular}{llrrr}
\hline Parameter & Sources of variation & df & Mean squares & F \\
\hline \multirow{4}{*}{ DFl } & Location & 1 & 3725.0 & $720.18^{* *}$ \\
& Block x location & 4 & 1.1 & $0.22^{\mathrm{ns}}$ \\
& Genotype & 35 & 335.4 & $64.85^{* *}$ \\
& Location x genotype & 35 & 56.4 & $10.91^{* *}$ \\
& Pooled error & 140 & 5.2 & $145.92^{* *}$ \\
\multirow{5}{*}{ Dmat } & Location & 1 & 427.9 & $3.48^{* *}$ \\
& Block x location & 4 & 40.9 & $144.71^{* *}$ \\
& Genotype & 35 & 424.3 & $40.55^{* *}$ \\
& Location x genotype & 35 & 118.9 & \\
\hline
\end{tabular}




\begin{tabular}{|c|c|c|c|c|}
\hline \multirow{5}{*}{ PHM $(\mathrm{cm})$} & Location & 1 & 10809.2 & $159.58^{* *}$ \\
\hline & Block x location & 4 & 280.9 & $4.15^{* *}$ \\
\hline & Genotype & 35 & 2887.7 & $42.63^{* *}$ \\
\hline & Location $\mathrm{x}$ genotype & 35 & 535.8 & $7.91^{* *}$ \\
\hline & Pooled error & 140 & 67.7 & \\
\hline \multirow{5}{*}{ Dia $(\mathrm{cm})$} & Location & 1 & 35.0 & $300.36^{* *}$ \\
\hline & Block x location & 4 & 0.9 & $7.86^{* *}$ \\
\hline & Genotype & 35 & 0.6 & $4.77^{* *}$ \\
\hline & Location $\mathrm{x}$ genotype & 35 & 0.3 & $2.56^{* *}$ \\
\hline & Pooled error & 140 & 0.2 & \\
\hline \multirow{5}{*}{$\mathrm{NbR}$} & Location & 1 & 12543.1 & $957.27^{* *}$ \\
\hline & Block x location & 4 & 132.7 & $10.13^{* *}$ \\
\hline & Genotype & 35 & 62.1 & $4.74^{* *}$ \\
\hline & Location $\mathrm{x}$ genotype & 35 & 35.4 & $2.71^{* *}$ \\
\hline & Pooled error & 140 & 13.1 & \\
\hline \multirow{5}{*}{ SW (g) } & Location & 1 & 5297214.2 & $252.37^{* *}$ \\
\hline & Block x location & 4 & 2993.6 & $0.14^{\mathrm{ns}}$ \\
\hline & Genotype & 35 & 58481.2 & $2.79^{* *}$ \\
\hline & Location $x$ genotype & 35 & 52527.8 & $2.50^{* *}$ \\
\hline & Pooled error & 140 & 20990.2 & \\
\hline \multirow{5}{*}{$\operatorname{HSW}(\mathrm{g})$} & Location & 1 & 15.0 & $268.20^{* *}$ \\
\hline & Block x location & 4 & 0.04 & $0.66^{\mathrm{ns}}$ \\
\hline & Genotype & 35 & 0.9 & $16.04^{* *}$ \\
\hline & Location $x$ genotype & 35 & 0.3 & $4.99^{* *}$ \\
\hline & Pooled error & 140 & 0.07 & \\
\hline
\end{tabular}

*: Significant at 5\% level. **: Significant at 1\% level. ns : not significant. df : degrees of freedom. M : mean squares. F : Ftest (Fisher test). DFl : number of days to flowering Dmat : number of days to $50 \%$ maturity, PHM : plant height at maturity, Dia : the basal diameter of the principal stem at maturity, $\mathrm{NbB}$ : number of branches per plant at maturity, SW : total seed weight per plant, HSW : 100-seed weight.

Table 6: Analysis of variance, with interaction as error source (mixed models).

\begin{tabular}{|c|c|c|c|c|}
\hline Parameter & Source of variation & df & M & F \\
\hline \multirow{4}{*}{ DFl } & Location & 1 & 3725.0 & $3284.12^{* *}$ \\
\hline & Block x location & 4 & 1.1 & \\
\hline & Genotype & 35 & 335.4 & $5.95^{* *}$ \\
\hline & Location $x$ genotype & 35 & 56.4 & \\
\hline \multirow{4}{*}{ DMat } & Location & 1 & 427.9 & $41.89^{* *}$ \\
\hline & Block x location & 4 & 40.9 & \\
\hline & Genotype & 35 & 424.3 & $3.57^{* *}$ \\
\hline & Location x genotype & 35 & 118.9 & \\
\hline \multirow{4}{*}{ PHM (cm) } & Location & 1 & 10809.2 & $38.48^{* * *}$ \\
\hline & Block x location & 4 & 280.9 & \\
\hline & Genotype & 35 & 2887.7 & $5.39^{* *}$ \\
\hline & Location $\mathrm{x}$ genotype & 35 & 535.7 & \\
\hline \multirow{4}{*}{$\operatorname{Dia}(\mathrm{cm})$} & Location & 1 & 35.0 & $38.23^{* *}$ \\
\hline & Block $x$ location & 4 & 0.92 & \\
\hline & Genotype & 35 & 0.56 & $1.86^{*}$ \\
\hline & Location x genotype & 35 & 0.30 & \\
\hline \multirow{4}{*}{$\mathrm{NbB}$} & Location & 1 & 12543.1 & $94.50^{* * *}$ \\
\hline & Block x location & 4 & 132.7 & \\
\hline & Genotype & 35 & 62.1 & $1.75^{*}$ \\
\hline & Location $\mathrm{x}$ genotype & 35 & 35.4 & \\
\hline
\end{tabular}




\begin{tabular}{|c|c|c|c|c|}
\hline \multirow{4}{*}{ SW (g) } & Location & 1 & 5297214.2 & $1769.54^{\text {** }}$ \\
\hline & Block x location & 4 & 2993.6 & \multirow{3}{*}{$1.11^{\mathrm{ns}}$} \\
\hline & Genotype & 35 & 58481.2 & \\
\hline & Location x genotype & 35 & 52527.8 & \\
\hline \multirow{4}{*}{$\mathrm{HSW}(\mathrm{g})$} & Location & 1 & 15.0 & $406.13^{* *}$ \\
\hline & Block x location & 4 & 0.04 & \multirow{3}{*}{$3.22^{* *}$} \\
\hline & Genotype & 35 & 0.9 & \\
\hline & Location x genotype & 35 & 0.3 & \\
\hline
\end{tabular}

Table 7: comparative mean performance of genotypes at the 2 locations and LSD value.

\begin{tabular}{lccc}
\hline \multirow{2}{*}{ Parameter } & \multicolumn{2}{c}{ Mean performance } & LSD \\
\cline { 2 - 4 } & Gaya & Maradi & 0.61 \\
DFl & $86.62 \pm 2.53$ & $78.31 \pm 1.97$ & 0.46 \\
DMat & $119.02 \pm 1.74$ & $116.21 \pm 1.67$ & 2.21 \\
PHM $(\mathrm{cm})$ & $164.71 \pm 8.67$ & $150.56 \pm 7.76$ & 0.09 \\
Dia $(\mathrm{cm})$ & $3.75 \pm 0.31$ & $2.94 \pm 0.36$ & 0.97 \\
NbR & $37.66 \pm 3.05$ & $22.42 \pm 4.10$ & 38.97 \\
SW $(\mathrm{g})$ & $443.24 \pm 202.78$ & $130.04 \pm 29.32$ & 0.06 \\
HSW $(\mathrm{g})$ & $3.85 \pm 0.28$ & $3.32 \pm 0.16$ &
\end{tabular}

LSD: least significant difference; DFl : number of days to flowering Dmat : number of days to $50 \%$ maturity, PHM : plant height at maturity, Dia : the basal diameter of the principal stem at maturity, $\mathrm{NbB}$ : number of branches per plant at maturity, SW : total seed weight per plant, HSW : 100-seed weight.

During 2002, $510.7 \mathrm{~mm}$ of rainfall was recorded on 40 days within six months at Maradi while in the more humid Gaya area; $856.9 \mathrm{~mm}$ of rainfall was recorded on 58 days during 7 months. Therefore, the two representative agroclimatic locations differed significantly both in terms of length of rainy season and amount of rain received.

Since important factors that affect seed production, such as the developmental cycle (number of days to flowering and maturity), plant height, number of branches and basal diameter, are influenced by the environment it is essential that selection programs for $H$. sabdariffa in Niger should consider the agro-geographical differences among genotypes.

\section{Conclusion}

Appropriate evaluation of genotype $\mathrm{x}$ location interactions is essential for effective plant breeding programmes. Many crops, particularly those grown in a wide range of agroclimatic conditions, require to be tested in fields in various sites because of highly significant genotype $\mathrm{x}$ location interactions. The findings of this study provide additional evidence that future varietal selection program for $H$. sabdariffa should consider location as an important decision factor.

\section{ACKNOWLEDGEMENTS}

The authors acknowledge the financial support provided by United Nations University Institute for Natural Resources in Africa (UNU-INRA) for the field research. The authors also thank Mr. Abdoulaye Maïkoudi and Haladou Moussa for providing technical assistance.

\section{REFERENCES}

Abou El-Seoud MA, Abd El-Sabour MF, Omer EA. 1997. Productivity of Roselle (Hibiscu sabdariffa L.) plant as affected by organic waste composts addition to 
sandy soil. Bull. Natl. Res., Center, Cairo, Egypt, 22: 495-505.

Babatunde FE. 2003. Intercrop productivity of roselle in Nigeria. Afr. Crop Sci. J., 11: 1-6.

Babatunde FE, Oseni TO, Auwalu BM, Udom GN, Ajayi JO, Mailabari BK. 2002. Influence of Nitrogen fertilizer and Variety on Quantity and Quality of Roselle (Hibiscus sabdariffa. L) Fibre. Science Forum, 5: 10-18.

Babatunde FE, Zachariah B. 2001. Effect of spacing and weeding regimes on the productivity of Roselle (Hibiscus sabdariffa. L). Advances in Horticultural Science, 14: 147-151.

Berhaut J. 1979. Linacées à Nymphéacées. In Flore Illustrée du Sénégal, Dicotylédones (Tome VI), J. Bérhaut (eds). Gouvernement du Sénégal, Ministère développement rural et de l'hydraulique, Direction des eaux et forêts. Librairie Clairafrique: Dakar, Sénégal ; 205-207.

Ibrahim SA, Mandour MS, Elneklawy AS, Selim AM. 1984. Nutritional requirements of Roselle (Hibiscus sabdariffa L.) plants under different levels and methods of fertilizers application. Egypt. J. Soil Sci. 26(2): 165-174.

Mansour BMM. (1975). Effects of temperature and day length on growth and flowering of Roselle, Hibiscus sabdariffa L. Scienta Hot., 3: 129-135.

Mcintosh MS. 1983. Analysis of combined experiments. Agron. J, 75: 153-155.

Morton JF. 1987. Roselle, In Fruits of Warm Climates. Greensboro CF Dowling (ed). NC Media Inc.; 281-286.

Nabila YN, MS Aly. 2002. Variations in productivity of (Hibiscus sabdariffa L.) in response to some agricultural supplementation. Faculty of Agrie. Ain Shams Univ., Cairo, Egypt. Ann. Agric. Sci., 47: 875-892

Panchoo L, Rhodin EG. 1990. Effect of transplant timing and terminal bud removal on Sorrel. Caribbean Food Crop Soc. Proc., 26: 245-254.

Rhoden EG, David P, Small T. 1993. Effect of nitrogen nutrition on Roselle. In New Crops, Janick J, Simon JE (eds). Wiley: New York; 583-584.

Saadou M. 1990. La végétation des milieux drainés nigériens à l'Est du fleuve Niger. Thèse présentée à la Faculté des sciences de l'Université de Niamey pour obtenir le grade de Docteur Es-Sciences Naturelles, 395 p.

Salah AE. 1977. Effect of different fertilization rates on the growth and yield of Roselle in Egypt. Indian J. Agric. Sci. 49 (2): 118-119.

SAS INSTITUTE INC. 1987. SAS/STAT User's guide. Cary, NC, USA: SAS Institute Inc.

Schippers RR. 2000. African Indigenous Vegetables: An Overview of the Cultivated Species. Natural Resources Institute/ACP-EC Technical Center for Agricultural and Rural Cooperation: Chatham, UK ; 214 p.

Sivakumar MVK, Maidoukia A, Stern RD. 1993. Agroclimatologie de l'Afrique de l'Ouest: le Niger. ICRISAT, information bulletin $\mathrm{n}^{\circ} 5$. Niamey, Niger. 67p.

Southern University Agricultural Research and Extension Center (2006). Food value of Roselle, Hibiscus sabdariffa-tea: Circular-Sustainable plant and animal production system $\mathrm{N}^{\circ}$. 303. 2p. 